Georgetown University Law Center

Scholarship @ GEORGETOWN LAW

1999

\title{
Ex Post Facto Payments in Legally-aided Criminal Cases in the Old Bailey
}

Peter W. Tague

Georgetown University Law Center, tague@law.georgetown.edu

This paper can be downloaded free of charge from:

https://scholarship.law.georgetown.edu/facpub/700

28 Anglo Am. L. Rev. 415-446 (1999)

This open-access article is brought to you by the Georgetown Law Library. Posted with permission of the author. Follow this and additional works at: https://scholarship.law.georgetown.edu/facpub

Part of the Criminal Law Commons, Criminal Procedure Commons, and the Legal Ethics and Professional Responsibility Commons 


\title{
EX POST FACTO PAYMENTS \\ IN LEGALLY-AIDED \\ CRIMINAL CASES IN THE OLD BAILEY
}

\author{
By PETER W. TAGUE
}

\section{Introduction}

A much more pervasive scheme for overseeing the reasonableness of fees charged by legal professionals exists in England than in the United States. In England, for example, with or without a specific agreement over the fee, the client can challenge the solicitor's charges, and the court or the Law Society will assess their reasonableness. 'Similarly, as part of assigning costs to the losing party, the reasonableness of the winning solicitor's claim for fees is evaluated. The lay client can even dispute the reasonableness of the barrister's fee after the fact.

In the United States, by contrast, lawyers hammer out agreements with private clients, in civil or criminal matters, that, except in contingency fee arrangements or with exploitative arrangements, are policed only by the lawyer's risk that the client will change

1. Specific citations to the points in this paragraph seem unnecessary. For a general review, see Steven Fennell, A Guide to Legal Costs (1993).

2. Although lawyers are expected to charge a reasonable fee, see American Bar Association, Model Rules of Professional Conduct, r.1.5(a) (1997), there is no easy way for the client to complain about a fee except to the local professional board. 
lawyers, lured by a more congenial fee. And with no legal aid in civil matters in America, private lawyers representing indigent criminal defendants are paid a set amount by hour, by act, or by case, almost never with any prospect of enhancement in light of the case's difficulty, and without much likelihood of review after the representation has ended to assess the reasonableness of the total fee sought.

Generally today in England, and before 1997 in the bulk of legallyaided criminal cases, the defending barrister's and solicitor's fees were fixed, as is universally true with lawyers' remuneration in parallel settings in the United States. In the most serious criminal cases underwritten by legal aid, however, until 1997 the defending barrister's and solicitor's fees were both calculated after each's representation had ended. The process of making those ex post facto calculations is the subject of this article.

There is good reason to examine this now-eclipsed method of paying legal professionals. As apparently the first attempt (or at least publicized attempt) to describe and evaluate the process of $e x$ post determination of legal professionals' fees, this study suggests the need to expand the inquiry, to examine ex post determinations in civil matters as well. An assumption of any scheme that has third parties test the reasonableness of a legal professional's claim for compensation is that the results are consistent and predictable within an acceptable range of deviation. ${ }^{3}$ Moreover, the legal professionals must be satisfied that the distinctions which lead one Queen's Counsel, say, to be paid less than another are justifiable. If these criteria are not met, it is possible that solicitors and barristers

3. One commentator predicts that because calculating a solicitor's fees (as well as a barrister's in ex post facto cases) is a matter of skill and judgment, not of unimaginative arithmetical calculation, it is "likely that different people will reach slightly different conclusions as to what is fair and reasonable in a particular case ...." Fennell, n.1, at 8 . Yet, it is also "likely that the amounts chosen by different people will tend not to diverge radically, because typical expense rates and the mark-up [for solicitors] for the locality and the work in question should be known ...." Ibid. (citations omitted). That second assumption is examined in this study. 
will refuse to represent certain sorts of lay clients ${ }^{4}$ or will be reluctant to perform some aspect of representation that they would otherwise undertake if not worried about being denied appropriate recompense.

Section II introduces the current and discarded systems of compensating defending advocates in legally-aided, criminal cases. Section III describes and evaluates the results of the examination of 63 files taxed or being taxed at the Old Bailey (the Central Criminal Court) in London. Section IV summarizes the results of the study.

\section{The Current and Discarded Payment Schemes}

From 1997 Parliament changed the way fees are calculated for advocates representing legally-aided criminal defendants in Crown Court. ${ }^{5}$ Under the former scheme, cases were divided into two types, standard and ex post facto (or non-standard). While the latter is the focus of this article, it is necessary to understand the difference between the two. Junior barristers (or solicitor-advocates) invariably appeared in standard-fee cases and were paid a fixed amount as a basic fee for preparation and the trial's first day, no matter how long they toiled in preparing, and for any subsequent trial day (a "refresher").

In ex post facto cases, by contrast, both the basic fee and any refreshers were calculated after the case had ended (hence the name) by a determining officer, ${ }^{6}$ employed by the Lord Chancellor's

4. Not bound by the cab-rank rule solicitors can elect whether to represent a potential client. While the cab-rank rule ordinarily forbids barristers from refusing a brief, it would be easy for a barrister to avoid a brief by professing to be booked or by regarding the expected fee (with non-legally-aided lay clients) as insufficient, conditions that lift the prohibition.

5. The Legal Aid in Criminal and Care Proceedings (Costs) (Amendment) (No.2) Regulations 1996 [hereinafter 1996 Legal Aid Regulations].

6. Determining officers are neither barristers nor solicitors, without legal, let alone advocacy training. Often beginning employment as a court usher, they might become a determining officer's helper, collecting and organizing data for the determining officer. As a determining officer, they often double as a Judge's courtroom clerk.

In High Court civil matters, by contrast, district Judges and taxing masters tax costs, along with senior executive officers of the Supreme Court Taxing Office. For a description, see Fennell, n.1, at 132-133. 
Department, based on various discretionary judgments. Standard fees were the norm. Ex post facto fees, invariably larger, ${ }^{7}$ were paid only when the offence charged was murder, manslaughter or one of a few other very serious crimes; ${ }^{8}$ the trial, regardless of offence, lasted longer than three days (or was expected to do so if the defendant had not pleaded guilty); or a "standard fee would be inappropriate taking into account all the relevant circumstances of the case ...."

Queen's Counsel's fees were automatically determined ex post facto because they are authorized to represent a legally-aided criminal defendant only when the charge is murder or the "case is one of [such] exceptional difficulty, gravity or complexity ... that the interests of justice require ... the services of two counsel. ${ }^{\prime 10}$ When a Queen's Counsel appeared," both he and his junior received a non-standard fee. ${ }^{12}$

In calculating an ex post facto fee, the determining officer reviewed the defence's file: the formal court documents, the solicitor's brief,

7. Payments were probably higher for two reasons: more time was presumably needed to prepare these more complex cases; more money was needed to lure Queen's Counsel to defend legally-aided criminal defendants, despite the cab-rank rule that ordinarily requires the barrister to accept any brief.

8. More specifically, the offence was designated as either a class 1 or class 2 offence. See "Guidelines on Counsel's Claims for Legal Aid Fees in Crown Court Proceedings", Archbold, Criminal Pleading, Evidence and Practice, Vol. 3, tables \& index, G-7 at 709 (1996) (Archbold).

9. The Legal Aid in Criminal and Care Proceedings (Costs) Regulations 1989, reg.9(2) [hereinafter 1989 Legal Aid (Costs) Regulations]. The Lord Chancellor conceded that this third criterion posed a "most difficult qualitative judgment ...." Lord Chancellor's Department, Directions for Determining Officers, Part 3 c.5(4) at 64 (1989). The factors included the skill needed to represent the defendant, the case's complexity or the "unusual position or standing of the defendant." Ibid.

10. The Legal Aid in Criminal and Care Proceedings (General) Regulations 1989, reg.48(2)(b).

11. The decision whether to authorize a leader to help represent the defendant is unrelated to the compensatory system under both the old and new schemes.

12. The junior typically received half of the Queen's Counsel's award, but might earn more or less depending upon the nature of his contribution. 
the witnesses' statements, the exhibits, the barrister's advice(s) on evidence, together with a form prepared by the barrister (or his clerk) indicating, among other points, the number of hours taken to prepare and the monetary amount requested. ${ }^{13}$ Barristers were also permitted to supplement this form by submitting a defence of the fee requested, explaining, for example, the case's difficulties that required considerable or subtle preparation and execution.

In 1993 the Bar proposed scrapping this scheme, ${ }_{14}^{14}$ and its proposal as modified was eventually adopted by the Lord Chancellor. Known as the graduated fee scheme, the new system eliminates the distinction between standard and ex post facto cases, and strips from determining officers most of their power to make discretionary judgments in setting both the basic fee and any refresher.

Each crime tried in Crown Court is now assigned to one of nine classes. Each class attracts a different, predetermined amount for the basic fee, depending upon the rank of the advocate (Queen's Counsel or "other advocate $\left.{ }^{\prime \prime 15}\right)$, and the method of resolving the case (by trial, guilty plea or cracked trial ${ }^{16}$ ). For example, if the defendant's prosecution for kidnapping (Class B) is resolved by trial, a Queen's Counsel receives a basic fee of $£ 1091$, an amount that swells to $£ 1143.50$ if the trial cracks and plummets to $£ 715.50$ if instead the defendant agrees to plead guilty before the trial date. If the same defendant was instead represented by only a junior or solicitor advocate, the advocate's basic fee would be $£ 311.50$ (trial), $£ 326.50$ (cracked trial) or $£ 204.50$ (guilty plea).

13. The determining officer could also gain a sense of the case from the form that solicitors had to submit to obtain compensation, in which was detailed virtually everything done by each fee-earner in the solicitor's employ for whose efforts compensation was sought. For example, the solicitor would list telephone calls, visits to the defendant in jail, conferences with counsel, sessions with prospective witnesses, time taken to write the brief.

14. The Bar reacted to the then-Lord Chancellor's (Lord Mackey's) proposal to extend standard fees to every case lasting less than 10 days, without regard to its complexity. Correspondence with John B. Milmo, QC, Chairman of Legal Aid and Fees Committee (June 11,1997).

15. The term implicitly recognizes that solicitors now can gain the right of audience to advocate on a defendant's behalf in Crown Court.

16. Acracked trial refers to a matter resolved by plea, typically on the trial's first day, when the case had instead been prepared for a fight at trial. 
A set payment is also provided for each day of trial after the first and for each page of the Crown's evidence and each Crown witness. ${ }^{17}$ The new system will be much easier to administer, in effect resembling the set fees in standard-fee cases under the old scheme. Determining officers will simply check whether the advocate's calculation of the fee due is accurate in light of the relevant criteria. Advocates will benefit in that payment should be made much more quickly than under the old scheme.

The Lord Chancellor seems to have had three reasons for adopting the new scheme. The major impetus was to control spiraling expenditure in criminal cases funded by legal aid. While payments to advocates are not reduced, ${ }^{18}$ the Lord Chancellor now has a way to control any increase in expenditure by adjusting the payments for each of the criteria (the basic fee, the refresher, and so on). ${ }^{19}$

A second reason was to simplify the calculation of payments. ${ }^{20} \mathrm{~A}$ third was to escape the vicissitudes of the determining officer's discretion. Indeed, the Lord Chancellor's Department worried that the awards made by "determining officers using their discretion

17. The payment for a trial day is called a refresher, to which an uplift automatically attaches. (Under the discarded scheme, by contrast, the determining officer chose the refresher's size in ex post facto cases.) To illustrate, if the kidnapping offense mentioned in the text were resolved at trial, a Queen's Counsel would receive $£ 413.50$ for each refresher and $£ 636.50$ as an uplift for each day of trial after the first, $£ 4.93$ for each page of the Crown's evidence and $£ 46.47$ for each witness the Crown called. For each refresher a junior acting alone would receive $£ 145.50$; as an uplift, $£ 182$; for each page of evidence, $£ 1.41$, and $£ 13.28$ for each witness.

18. The Bar thus prevailed in its fight to prevent any reduction in the fees.

19. See Anthony Berry QC, "Graduated Fees in the Crown Court," May/June 1996, Counsel, at 12. The Lord Chancellor was especially concerned over mounting expenditures in ex post facto cases. In the years 1991-1995, for example, increases in aggregate fees received by leading counsel significantly outstripped inflation. Communication from the Lord Chancellor's Department. Nonetheless, predicting the legal aid cost of the defence in criminal cases will remain difficult because the overall cost will fluctuate in light of the number and types of cases, and the number of cases to which the new scheme does not apply.

20. No longer, for example, will advocates need to keep a record of what they did and the time needed to complete their work. 
lacked consistency or predictability," and even suspected that barristers were rewarded for inefficiency because paid a higher basic fee simply "for doing more hours of work."

Those accusations leveled against determining officers were not publicly documented. Indeed, it appears that no study was undertaken to grade the determining officers' work in terms of consistency, predictability and reasonableness.

Failing to test the determining officers' efforts seems peculiar for one reason germane to the new scheme and for another, more general reason. The parochial reason is that not all discretionary judgments have been wrung from the new scheme. Determining officers will continue to exercise judgment in a number of instances. For example, a barrister who returns the brief will not be paid for preparation unless the determining officer finds that "the hours of preparation [were] reasonably carried out ...."22 Also, the new system does not apply in long or presumably complicated cases, ${ }^{23}$ where the advocate's fee will continue to be selected by a determining officer after the case ends. If determining officers can be trusted to make

21. Communication from the Lord Chancellor's Department.

22. 1996 Legal Aid Regulations, n.5, sch.3, para.18(3), at 15. There are also other conditions, including the need for the trial to last at least five days or, if the trial cracks, the prosecution's evidence exceeded 150 pages. Ibid. para. 18(2).

23. This is so when the prosecution's evidence at trial exceeds 1,000 pages or 80 witnesses; with a trial, estimated to last 10 days that cracks instead, its evidence exceeds 250 pages or 80 witnesses; and when the defendant is expected to, and does, plead guilty, its evidence exceeds 400 pages or 80 witnesses. Ibid. sch.3, para.2(2) at 9. 
these judgments, ${ }^{24}$ why could their decisions under the old scheme not be trusted, too? Even if the new scheme would have been adopted solely to better control overall expenditures, these remaining instances of discretion make it important to examine whether determining officers acted arbitrarily or sensibly in ex post facto cases, as a way of predicting how they will exercise their new, now narrower jurisdiction.

The more general reason to have inspected the determining officers' awards is the loss of an opportunity to begin the process of examining the rationality of third-party awards in all areas, and not simply in legally-aided criminal defence work. It would have been natural to grade the determining officers' efforts as part of the process of deciding whether and how to revise the payment scheme in legally-aided criminal defence work. With such an effort as a pilot project, further research might have been suggested which could have informed the Lord Chancellor's plans for reform of the civil justice system and its funding. Moreover, even with no groundswell of discontent among legal professionals in non-criminal areas about the fees they receive, an occasional inquiry about the process is important to ensure that the professionals are being treated as expected and that the awards are acceptably consistent and predictable.

24. There are others as well. To be paid for attending a conference with an expert witness or for travelling to and from a prison to attend a conference with the defendant, the advocate must convince the determining officer the "work was reasonably necessary ...." Ibid. sch.3, para.19(1). The determining officer must likewise find that the preparation was "reasonably done" when a barrister seeks an interim payment for having worked at least one hundred hours in a case that will not likely be resolved within a year of the committal. Ibid. para.7, at 2 (inserting reg.4F into the law). As the determining officer can reduce the predetermined fee when the judge criticizes the advocate's "conduct of the case," ibid. para.10 at 6 (amending reg.9), so she can increase it if because the case "involves a very unusual or novel point of law or factual issue ... preparation substantially in excess of the amount normally done for cases of the same type" is needed. Ibid. sch.3, para.17. For the other instances, see Lord Chancellor's Department, "Guidance to Determining Officers on the Graduated Fee Scheme in the Crown Court and Example Fee Calculations" (March 1997), para.1. Last, the graduated fee scheme does not apply to solicitors, whose requests for an uplift continue to be evaluated by determining officers. 
The next section describes and evaluates how determining officers made ex post facto awards in 63 cases taxed at the Old Bailey. ${ }^{25}$ To anticipate the conclusion, the cases in this study support one of the Lord Chancellor's concerns about the determining officers' awards, but not the other. The awards were often unpredictable, but barristers were not paid more simply by working longer hours. That first concern ought to prompt the Lord Chancellor both to provide more instruction under the new, graduated fee scheme for determining officers in those areas where they retain jurisdiction, and to undertake a similar examination of the way fees are chosen in civil cases. ${ }^{26}$

\section{Fees Paid in the Cases Studied}

This part concentrates on the fees paid to barristers under the old scheme, but ends with a brief examination of the amounts received by solicitors in the same cases.

\section{i. Fees to barristers}

Ordered to "allow [the barrister] a reasonable amount in respect of all work actually and reasonably done, ${ }^{\prime 27}$ the determining officer's responsibility in ex post facto cases was daunting. She was first

25. While the study was conducted in 1992, the methods of calculating fees did not change until the graduated fee scheme was instituted in 1997. I did not interview either the defending barristers and solicitors or the determining officers who calculated the payments. The former were unaware I had received permission to review their otherwise confidential submissions. It did not prove feasible to interview the determining officers to ask them to explain or defend a given payment.

26. A shift to a different system, like the current graduated fee scheme, obviously can also change a legal professional's incentives to perform effectively and efficiently. There seems to be no evidence that in fashioning the graduated fee scheme the Lord Chancellor (or the Bar) considered this issue, a matter I hope to explore at a different time.

27. 1989 Legal Aid (Costs) Regulations, n.9, reg. 4(2). The determining officer could ordinarily award any amount up to a ceiling, but could breach that ceiling in "exceptional circumstances". Ibid. reg. 9(5)(b). For the amounts as of 1995, see Archbold, n.8, Vol. 1, §6-276, at 1/1085. 
expected to test whether the barrister had worked the hours claimed and then to evaluate whether he had worked efficiently in light of "all the relevant circumstances of the case including the nature, importance, complexity or difficulty of the work and the time involved ...." ${ }^{\prime 28}$

No barrister was grilled over the hours he said he took to prepare. Nonetheless, while there was no evidence that any determining officer believed a barrister had bloated his preparatory time, the times given in several cases appeared to be so exaggerated as to justify inspection. Were inflation suspected, however, it was apparently more convenient to skirt a messy inquiry and simply conclude that the barrister had prepared inefficiently, and thereby slice the time for which compensation would be paid. Through this ostensibly polite ruse, the determining officer left unsullied the barrister's reputation for veracity, but punished him for having performed too slowly.

Having a determining officer evaluate the barrister's efficiency exposes the central problem in the ex post facto scheme. Without training or practice as an advocate, how could a determining officer appreciate the problems confronting the advocate and the choices he

28. Ibid. reg.4(2)(a). One commentator regarded the effort as even more imposing: "It is impossible to state all the factors or the weight to be attached to any individual factor which may be taken into account in assessing non-standard fees." Archbold, n.8, tables and index, "Guidelines on Counsel's Claims for Legal Aid Fees in Crown Court Proceedings", para.G-27 at 715 . 
made ${ }^{29}$ True, doubling as Judges' clerks, determining officers would have observed many trials and would know the barrister's reputation (clever or inept, swift or slothful, insightful or dull). Yet, even with that knowledge, how could a non-advocate conclude that a barrister who said he had expended 16 hours to prepare instead needed only 12 to peruse the brief, identify the applications to make and the arguments to advance, select the witnesses to call and the evidence to adduce, plot the cross-examination of the Crown's witnesses and fashion the final speech to the jury? ${ }^{30}$

There were two ways for the determining officer to simplify her imposing responsibility of evaluating the barrister's efficiency: rely on the presiding Judge's praise or criticism of the barrister's performance; ignore the tangle of facts presented by every barrister's request for compensation and instead automatically discount the time said to have been taken by a predetermined percentage. The first way proved of scant value in the cases studied

29. Compounding these evaluative problems was the paucity of information provided by many barristers. While the professionals were expected to detail their conduct, in practice only the solicitors provided enough information to map their efforts. For example, most barristers failed to divide their preparation into its components - the time taken to research a point of law, for example, or to mull over how to examine a witness - and instead simply gave a summary figure of, say 15 hours. And the explanations offered by barristers who did name the difficulties they faced were often more self-serving or exaggerated than enlightening. In one typical example, two of three reasons offered by a junior in defence of his request for non-standard payment in a one-day trial were unremarkable (the defendant was a person of good character who risked incarceration if convicted). The third reason - an interpreter was needed to understand the victim - was unusual but did not appear to complicate the junior's representation.

30. Despite many puzzling awards, only two barristers sought more money by appealing the determining officer's decision. The inference from the apparent lack of appeals is uncertain, but probably not an indication that barristers supported the process. More likely, they either tolerated it begrudgingly or saw no way successfully to object to a process they found unsatisfactory. 
because Judges commented so infrequently. Even if Judges had praised or criticized barristers more often, however, determining officers might have ignored the comment because of the procedural regime that had to be met before the comment could be considered. ${ }^{32}$

There was no evidence determining officers used a standard discount, despite barristers' belief to the contrary. ${ }^{33}$ Such an

31. Only one barrister was criticized (for verbosity) and three were praised (for unidentified submissions). While it is not clear whether the determining officers were affected by these judicial comments, the criticized barrister in case number 5 might have been. (A case is numbered if mentioned more than once.) This junior represented a defendant charged with robbery; the co-defendant, charged additionally with a murder in connection with the robbery, was represented by a Queen's Counsel and a junior. The Judge complained that the first junior's prolix cross-examinations might have caused the trial to last as long (10 to 12 days) as she had predicted rather than the seven days estimated by the Queen's Counsel. (The trial ended even sooner when the Judge directed the jury to acquit.) In his note to the determining officer the Queen's Counsel also observed that, but for his waiver of the Crown's obligation to adduce certain evidence, the junior's protracted cross-examinations would have caused the trial to last longer than it did. These criticisms probably led the determining officer to punish this junior because her gross award was less that that of the co-defendant's junior, as were her refreshers (by $£ 10$ a day) and her effective hourly rate ( $£ 45$ as against $€ 61$ ). (I derive the "effective hourly rate" by dividing the basic fee by the number of hours the barrister took to prepare plus five hours for the trial's first day whenever the case as tried.)

32. A passing censorious comment offered during the proceeding did not count unless the Judge made the point formally (or the determining officer asked the Judge whether he intended the carp to count). Then, the barrister had to be given an opportunity to respond. This rather cumbersome procedural regime continues under the new scheme, even while Judges are encouraged to comment. See 1996 Legal Aid Regulations, n 5, reg.9(a)(2A).

The relationship between this method of penalizing an advocate and a wasted costs order is now clear. The defendant's legal representative can be made to pay the wasted costs of any party (including the Crown) "as a result of any improper, unreasonable or negligent act or omission ...." Prosecution of Offences Act 1985, reg. 19A. Such a payment applies when a specific act wastes the court's time. The advocate's basic fee is instead docked when the Judge is "general[ly] dissatisf[ied] with the [advocate's] conduct of the case ...." Guidance to Determining Officers, n.24, para. 12.

33. See The Senate of the Inns of Court and the Bar, Study of Remuneration of Barristers Carrying out Criminal Legal Aid, para.1.33 at 15 (1985) (reductions of $25 \%$ suspected). 
approach would have been defeated by barristers who simply inflated the amount they hoped to receive by the expected discount rate. Moreover, it was inconsistent with the nuanced evaluation seemingly expected in determining a reasonable fee. Although barristers' requests were almost invariably reduced - not a single junior, acting alone, received what he sought, and only two of 20 Queen's Counsel did ${ }^{34}$ - these reductions were made by inspecting each case. For example, of the requests by Queen's Counsel, the smallest reduction from the amount requested was $13 \%{ }^{35}$ and the largest, $53 \% .^{36}$

The marked variation in the percentages disallowed was probably caused more by the exaggerated amounts requested by the

34. One of these two instances (number 31) was understandable because the Queen's Counsel had anticipated the Crown would let the defendant plead guilty to manslaughter. Notified on Friday that the plea was unacceptable, the Queen's Counsel had to scramble over the weekend to prepare for trial on Monday. On Monday, he convinced the Recorder to persuade the Crown to accept a plea. It did. For 22 hours of preparation he sought and received $£ 3,000$ (an effective hourly rate of $£ 135$, again not counting the time taken on the hearing date), an appropriate fee in light of the trial time he saved and the unexpected need to prepare for trial.

35. While this Queen's Counsel received only $£ 500$ less than the $£ 4,000$ he sought, his effective hourly rate was $£ 95.5$ ( 32 hours of preparation), much lower than that garnered by most other Queen's Counsel in the study.

36. In this case (number 28) the defendant changed his mind on the day of trial when the Crown offered to let him plead guilty to a lesser count than the offence charged (attempted murder). The defending Queen's Counsel submitted a folder in which heargued that the plea avoided a four-day trial, and reviewed the defendant's position about a trial or a plea, the Crown's and defence's cases, and his difficulties during the sentencing (he called several witnesses to testify about the defendant's mental problems). Despite his efforts to defend his work, his request for $€ 6,250$, involving 22 hours of preparation, was reduced to $£ 3,000$. Although the percentage reduction was extreme, the probable explanation is that he apparently did little if anything to contribute to the guilty plea. See below n.46. And his effective hourly rate was $£ 136$ per hour, handsome even if less than other barristers received in cracked trials.

The requests by two other Queen's Counsel in cases that were tried were reduced by $50 \%$ and $47 \%$. The effective hourly rate of the former was $£ 114$ (the defendant pleaded guilty after the Crown opened) (number 9); of the latter, $£ 91.5$ (number 22). 
barristers (or, more likely, by their clerks), perhaps in hope that the request would itself induce the determining officer to award a generous fee. Several of the requests were breathtakingly high, with the acme that by a Queen's Counsel who asked for an effective hourly rate of $£ 860$ (reduced to $£ 535$ ) (number 14). The next highest was $£ 625$ (slashed to $£ 231$ ). Juniors who acted alone were less prodigal in their requests; the highest effective hourly rate sought was $£ 200$ (he got $£ 140$; the trial cracked). Even ignoring the inflated requests, the effective hourly rates were scattered widely for Queen's Counsel and for juniors who themselves represented the defendant.

If determining officers eschewed a standard discount and exuberantly slashed the amounts requested, the core question remains to be answered: ${ }^{37}$ how could a person without experience as an advocate, who worked with incomplete and sometimes skewed information and who did not query the advocate about his

37. These problems remain under the current scheme in those fewer instances where determining officers continue to make discretionary judgments about the advocate's work.

Determining officers nonetheless did receive guidance under the old scheme. See Directions for Determining Officers, n.9, and Taxing Officers' Notes for Guidance [hereinafter Tong]. Moreover, they began to learn about the process by first taxing requests of less than $£ 500$; then, over time, graduated to claims up to $£ 4,000$, the maximum jurisdictional amount that determining officers in a Crown Court ordinarily could award. Demonstrating aptitude, the determining officer would be trained to tax those claims between $£ 4,000-8,000$ returned by the Circuit's Central Taxing Team (whose jurisdiction covered claims of higher amounts). Of the determining officers in the Old Bailey's Crown Court taxing group, in 1996 only three were qualified to tax these cases returned by the Central Taxing Team. Conversation with determining officer (July 1996). Nonetheless, determining officers were apparently not tested in any systematic way, by being asked, for example, to tax the same files to see if uniform results were obtained. One determining officer did tell me, however, that he would occasionally review the awards chosen by his subordinates, and urge a change whenever his calculation of the appropriate amount deviated by more than $10 \%$ from that chosen. 
decisions, place herself in the advocate's position to determine the preparation needed and the time necessary to complete it? ${ }^{38}$

No single, simple answer to that question emerges from this study. Instead, determining officers followed several policies, both published and unpublished.

\section{A. Publicized policies ${ }^{39}$}

Shortening the proceeding

Barristers could be rewarded for shortening the proceeding ${ }^{40}$ In effect, the barrister captured part of the money he would have received if, but for his contribution, the case had lasted as long as expected. This rule reduced the barrister's incentive to recommend a fight when a guilty plea was more appropriate or, once in trial, to demand proof of every point the Crown must establish. ${ }^{41}$

38. Determining officers were expected to evaluate the skill needed to represent the defendant, and thus the skill demonstrated by the barrister (and solicitor). As examples, the determining officer had the authority to reconsider whether it was appropriate to appoint a Queen's Counsel, see Tong, n.37, para.44 at 16; to consider whether a long trial was not difficult, ibid. para.30 at 12, or was "unduly prolonged by lack of preparation," ibid. para.28 at 11; whether the barrister "properly" shortened the trial, ibid. para.33 at 13; and, in general, whether the fee reflected the weight of the case and the skill and responsibility needed, $i b i d$. para.38 at 14 .

39. Another rule was the irrelevancy of the outcome. Thus, it did not matter that a conviction or acquittal was a surprise, so that, accordingly, the barrister arguably acted ineptly (when the defendant was convicted) or brilliantly (when acquitted). These salutary points reminded the determining officer not to be affected, in selecting an amount, by her pleasure or dismay at the outcome.

40. In R. v. Bellas, Taxing Compendium, C9 (Aug. 1985), a taxing master recognized that "where the efforts and skill of counsel are responsible for the case going short, thereby serving his client's best interest, saving the court's time and assisting the public interest by the prompt despatch of business", the barrister ought to receive a higher fee.

41. Whether this rule induced barristers inappropriately to shorten the proceedings is an important question discussed briefly in the next part. 
Barristers were rewarded for shortening the time needed to resolve the case. ${ }^{42}$ For Queen's Counsel, in all but one case the effective hourly rate was higher for a cracked trial than for a trial. ${ }^{43}$ The peaks ( $£ 535$ and $£ 300$ ) were given in a single case where three defendants pleaded guilty on the day of trial, thereby eliminating, according to the Judge, the need for a five-day trial (number 14). ${ }^{44}$ However, the basic fee did not invariably swell when the trial cracked. In number 28 a Queen's Counsel representing a defendant charged with attempted murder sought a basic fee of $£ 6,250$ for 22 hours of preparation, but received only $£ 3,000$, the largest reduction by percentage of any leader. This Queen's Counsel's effective hourly rate of $£ 136$ was significantly less than that received by Queen's Counsel in other cases that cracked, and even less than that received by Queen's Counsel in four cases that went to trial. ${ }^{45}$ With nothing

42. While barristers also expected higher compensation when the trial itself ended more quickly than expected, the awards in the study's cases were varied and inexplicable. Consider two cases that ended on the trial's first day. In a prosecution of manslaughter (number 5) a Queen's Counsel received a generous effective hourly rate of $£ 231$ when the case was stopped as the Judge accepted the defence's argument over the defendant's responsibility. Yet, in a case (number 22) that ended when the defendant pleaded guilty after the Crown had opened, the Queen's Counsel received a comparatively paultry basic fee of approximately $£ 114$. Nothing in these files distinguishes one case from the other to explain this disparity in awards.

43. Under the new scheme advocates will also receive somewhat higher fees when the trial cracks than when the jury decides the outcome. As illustration, see text following n.16.

44. The first Queen's Counsel sought $€ 6000$ for seven hours of preparation (a rate of $£ 860$ per hour) and received $£ 3,750$. Representing a co-defendant, the second Queen's Counsel received $£ 4,500$ (of $£ 8,000$ requested) for 15 hours of preparation. A third Queen's Counsel, representing a third defendant, also received $£ 4,500$, but his effective rate was less, $£ 225$ per hour, because he had taken 20 hours to prepare. The file contained too little information to explain the differences in effective hourly rates, or to evaluate whether the outcomes-guilty pleas to lesser offences - were appropriate.

45. Those effective hourly rates were $£ 200$ (number 48), £148 (number 3 ) and $£ 140$ (twice, numbers 44 and 45). 
in these files to explain this gaping difference in compensation, ${ }^{46}$ number 28 is one of many awards that belies the professed uniformity of awards. ${ }^{47}$

\section{Doing only work that demanded one's skills}

A more experienced professional was not supposed to undertake work that a less experienced, and thus less expensive, professional could perform..$^{48}$ In effect, this policy established a pyramid: forming the base was the solicitor who with his staff would need more time to prepare than would the advocate(s); in the middle was the junior who helped the solicitor to assemble evidence, and then distilled it while advising the leader; at the top was the leader who was expected to concentrate only upon the important issues and to rely on the work of the junior and solicitor.

46. The difference is striking when the award in number 28 is compared with that received by a Queen's Counsel in another case that cracked, number 18. Number 18's Queen's Counsel received an effective rate of $£ 250$ per hour even though he (like the leader in number 28) appeared to do nothing to cause the trial to crack. Because each's defendant wanted a trial, neither discussed a plea with the Crown before the date of trial, and neither indicated that he had to persuade the defendant or the Crown to accept the plea to the reduced charge. Indeed, the Queen's Counsel in number 18 seemed to contribute nothing to the outcome because his defendant was permitted to plead guilty to robbery, with the murder charge dropped, only because the co-defendant's leader produced a psychiatric report that convinced the prosecuting barrister to accept his lay client's guilty plea to manslaughter. There might be a way to explain the marked imbalance between the effective hourly rates received by the Queen's Counsel in these two cases, but none flies from the files.

47. When juniors represented the defendant by themselves, their basic fees, consistent with the Lord Chancellor's policy, were usually higher in cracked trials than in trials. The highest basic fee, of $£ 140$ per hour, went to the junior who took less time to prepare (five hours) than all but one other junior. While this junior's lay client pleaded guilty, it was not clear how the junior contributed to that decision. Juniors in two other cases where the defendants pleaded guilty received considerably less per hour, $£ 68$ and $£ 59$. Those amounts were also less than the highest basic fee ( $£ 81$ ) awarded to a junior whose defendant went to trial. From 181 , however, the basic fees for juniors in trials dropped next to $£ 64$, and then plummeted from the mid $-40 \mathrm{~s}$ all the way to $£ 26$, the lowest hourly rate received by a junior.

48. See Tong, n.37, para. 107 at 35 . 
The basic fees in three cases resolved at trial appear to illustrate this pyramidal policy. In number 5, a murder prosecution, a Queen's Counsel took eight hours to prepare, asked for $£ 5,000$ as a basic fee, and received $£ 3,000$, for an effective hourly rate of $£ 230 .{ }^{49}$ In number 6 , a prosecution for rape, a Queen's Counsel sought $£ 4,200$ as a basic fee for 21 hours of preparation, and received $£ 3,000$, for an effective hourly rate of $£ 115 .^{50}$ In number 9 , a prosecution for robbery and escape, a Queen's Counsel needed 36 hours to prepare, sought $£ 7,000$, but received only $£ 3,750$, for an effective hourly rate of $£ 91 .{ }^{31}$

While the determining officers left no clues to explain these three awards or the disparities among them, a plausible explanation is a violation of the pyramidal relationship. Because the Queen's Counsel in numbers 6 and 9 took more time to prepare than did each's junior, they were effectively punished for having undertaken work that the junior (or solicitor) should have done. Did these Queen's Counsel mistake the leader's role? Did each find the junior's performance unsatisfactory? Did he fail to manage a junior who was shirking his responsibility? There are no answers, but the results are intriguing in several ways.

First, these disparities disprove the Lord Chancellor's suspicion that a linear relationship existed between the length of preparation and the compensation awarded by determining officers. Indeed, an inverse relationship seemed to exist. The effective hourly rate rose when the barrister took less time to prepare, and sank as he took longer.

49. If this Queen's Counsel had received the amount he requested, $£ 5,000$, his effective hourly rate would have been a rich $£ 625$. The junior sought $£ 3,333$ as a basic fee, but was given only $£ 1,250$, half of the amount originally received by the leader (whose fee increased by $£ 500$ when he complained). While the file unfortunately does not indicate how long the junior took to prepare, his four-page explanation of his efforts suggests that the leader could spend as little time as he did in preparing because of the junior's thorough work.

50 Unlike the first example, this Queen's Counsel's junior spent less time to prepare (12 hours) than did the Queen's Counsel. Nonetheless, the junior received half the leader's award, $£ 1,500$, for an effective hourly rate of $£ 88$.

51. At $£ 7,000$ his effective hourly rate would have been $£ 170$. His junior sought $£ 3,500$ as a basic fee for 12 hours of preparation, and received $€ 1,875$, half the leader's award, for an effective hourly rate of $£ 110$. 
Second, this policy could have had a deleterious effect on a leader's advocacy. It created a disincentive for a leader to oversee a fumbling junior, or even to expend the time he thought necessary to prepare thoroughly. 52

Third, these cases illustrate the fortuity of the junior's award under the old scheme. In number 9, the junior's effective hourly rate ( $£ 110$ ) exceeded his leader's ( $£ 91$ ). Moreover, when compared with the fees received by the barristers in number 6 , this junior's hourly rate dwarfed that other junior's return ( $£ 88$ ) by $£ 22$ an hour even though they both spent the same time to prepare, and almost matched the other leader's hourly earnings (£115). These anomalies occurred because a junior's award was almost always half the Queen's Counsel's, ${ }^{53}$ and the leader's gross payment (but not his effective hourly rate) was often higher the longer he took to prepare.

\section{B. Unpublished policies}

While the published policies help to explain certain awards, they did

52. While now irrelevant under the graduated fee scheme, this policy suggested that the leader needed to explain why he had taken so much time to prepare or why he had not demanded more effort from the junior, but few did. And unfortunately, the barristers never explained how they worked together.

53. The junior could be paid more than half in rare cases where he undertook more responsibility than expected. In one case a junior received more than half when forced to represent the defendant by himself until near the trial because of the difficulty in retaining a leader, and another similarly benefitted when he too was forced to assume more responsibility than normal because his leader was reluctant to speak with the defendant or to prepare.

The junior could also receive less than half. In one murder prosecution (number 18), for example, the junior sought $£ 2,000$ for 20 hours of preparation, and received $£ 1,750$ (an effective hourly rate of $€ 70$ ). His leader, by contrast, requested $£ 5,000$ for 17 hours of preparation, and received $£ 4,250$ (an imputed hourly rate of $£ 193$ ). For two reasons, this junior's award of less than half his leader's is inexplicable. First, the junior performed very well. Second, the co-defendant's Queen's Counsel received $£ 4,250$ (for 20 hours of preparation) and his junior half that amount ( $£ 2125$ ). This second junior worked the same number of hours as the first junior. Nothing in the file explains why the second junior was paid more than the first. 
not provide sufficient direction to decide the compensation in any given case or to ensure that awards would be consistent. For example, how should the work of two Queen's Counsel defending accused murderers in unrelated proceedings be compared, when one reported having taken 15 hours to prepare and the other 30 ? Should the determining officer search for differences in the difficulties posed by each case? Assess the relative acuity of each advocate? Assume all Queen's Counsel were fungible, and thus pay the second more (if not double) the basic fee given the first because the longer time the second took to prepare reflected that case's greater difficulties?

While it would have been useful to develop a matrix that incorporated the type of crime, the barrister's experience, the time taken to prepare, the difficulty of the case and so on, there was no evidence in the study that anything so formal was attempted. Determining officers, however, did simplify their task by making assumptions about the average time needed to prepare certain types of cases and by comparing the times taken by different barristers in the same case. These assumptions brought some predictability, if not fairness, to the compensation awarded in many cases.

\section{Average time needed to prepare}

One determining officer told me that in a five-day murder trial a Queen's Counsel was expected to need between 10 and 30 hours to prepare, with the median hovering around 20 . Hence, to avoid receiving a lower effective hourly rate a Queen's Counsel who took more than 20, and surely more than 30 hours to prepare had to offer a compelling explanation for the additional time. Conversely, a Queen's Counsel who took less than 20 hours to prepare would be compensated as if he had prepared more extensively, on the assumption, apparently, that he had acted efficiently, and his efficiency should be rewarded.

The basic fees at the extremes suggest that such a benchmark was

54. While developing benchmarks for particular offences would simplify the determining officer's burden, their use could result in over or under compensation. The assumption seemed to be that barristers were not fungible, so that any barrister who took less than 20 hours to prepare had worked expeditiously, and any who took longer had been slothful. Yet, it 
used.$^{54}$ In the murder cases tried to verdict, the Queen's Counsel who took the least time to prepare (eight hours) received the highest effective hourly rate (£231) (number 5) and two of the three Queen's Counsel who took the most time ( 60 hours, $£ 83$ per hour; 32 hours, $£ 108$ per hour (number 32$)$ ) received the least. ${ }^{55}$ Similarly, in the three prosecutions for rape the Queen's Counsel who worked the least (21 hours, $£ 115$ per hour (number 6)) received much more, on an hourly basis, than did the other two who laboured longer than 30 hours ( 36 hours, $£ 91.50$ per hour (number 9)); 32 hours, $£ 95.50$ per hour (number 32)).

\section{Comparing the efforts of different barristers}

In cases involving co-defendants or a returned brief, determining officers selected an average time needed to prepare by comparing the efforts of the different barristers. In one case involving co-

seems equally plausible to predict that barristers were fungible, so that, given the mix of facts and issues in a particular case, other QCs would have taken the time to prepare as did the leader who represented the defendant, whether that number was 10 or 30 hours. No matter how inexact the use of a benchmark might be, the lesson for barristers was clear (and remains so under the new scheme when the barrister seeks an amount that exceeds the ordinarily ordained payment): to document why the case demanded the time taken to prepare when that time exceeds what is commonly expected.

55. In a third case the Queen's Counsel received an inexplicably generous hourly rate of $€ 122$, for 40 hours of preparation. 
defendants ${ }^{56}$ the extremes were extraordinary. Six defendants, charged with murder, were each represented by a separate Queen's Counsel. The first Queen's Counsel took 30 hours to prepare; the second, 121 hours; the third, 292 hours; the fourth, 89 hours; the fifth, 110 hours; the sixth, 100 hours. ${ }^{57}$ The determining officer concluded that the benchmark for preparation would be between 100-120 hours. Thus, rather than branding the third Queen's Counsel's claim as a transparent exaggeration, the determining officer achieved the same effect by crediting him with at most $40 \%$ of the seven weeks he

56. In another (number 33) the comparison produced an unfair result as measured against the ostensible skill needed to achieve the outcomes. Two adults and a 13-year-old, charged with kidnapping and torturing the victim, were each represented by a junior. All three pleaded guilty: the two adults immediately before the jury was impaneled, the juvenile at the close of the Crown's case. The outcome for the juvenile, who was the most culpable, was surprisingly generous: a plea to false imprisonment and no incarceration. The juvenile's junior sought $£ 2,500$ as a basic fee for 18 hours of preparation. That amount was slashed to $€ 600$, for an effective hourly rate of $£ 26$, the same hourly rate a junior would receive in a standard-fee case that he took three hours to prepare ( $£ 214$ divided by eight (three hours of preparation and five hours for the trial's first day)). This miserly amount can only be explained because the determining officer, noting that the other two juniors had taken only eight hours to prepare, thought the junior had wasted time in his preparation. That conclusion seems unfair for several reasons: he shouldered more responsibility because his defendant was the most culpable and the most difficult to defend, as illustrated by the Judge's confusion in understanding the sanctioning choices. Indeed, the Judge praised this junior for his thorough research and able argument in defence of an (unsuccessful) application for a directed acquittal.

The juvenile's senior solicitor, who undertook all the preparation, was similarly punished. Not only was he denied the uplift he sought, but he was remunerated at the lower hourly rate of a solicitor. Moreover, he was paid for only a little more than half the time he took to write the brief (three hours and 45 minutes rather than six hours and 30 minutes). Whereas the determining officer explained why he bloodied the junior's request, he gave none for punishing the senior solicitor.

57. The determining officer who showed me the case discussed in the text mentioned another untaxed case in which the preparation times were also scattered. The first junior took five hours to prepare; the second, 40 hours; the third, 75 hours; the fourth, 90 hours. The determining officer expected that the benchmark for preparation would be around 50 hours, with the result that the first two juniors would be paid more than their time might merit on its own, the second two, less. 
claimed to have taken to prepare. Conversely, the first Queen's Counsel would be compensated as if he had worked 70 more hours than he had.

Reducing the third Queen's Counsel's claim seems legitimate. The figure is so excessive that an error in its recording might have occurred. Moreover, he said nothing in his submission to justify the time he took. Increasing the first Queen's Counsel's claim is more problematic. Because he represented the ringleader, was he cavalier in taking no more time than he had? Or, was his solicitor's brief so thorough that he could prepare quickly ${ }^{38} A$ third explanation seems most plausible. Because there was little evidence, apart from the defendant's admissions, connecting the defendant to the crime, this Queen's Counsel did not expect to do much during the trial. He could prepare quickly and trust that his colleagues would challenge the Crown's other evidence. The first Queen's Counsel thus could probably ride freely on the preparatory work done by the others. Yet, if that were so, why should he be paid so handsomely for less involvement? Whatever the reasons for the hours logged by the first and third Queen's Counsel, increasing the first's compensation seems no less problematic than decreasing the third's. ${ }^{59}$

The preparation by the juniors in this case may help to explain the wildly different times taken by the first and third Queen's Counsel. The first Queen's Counsel's junior took 150 hours to prepare; the third's, only 49 hours. The first Queen's Counsel probably relied upon his junior's extensive preparation, while the third Queen's Counsel perhaps needed more time to prepare because his junior had worked much less. The first Queen's Counsel was rewarded for having relied on his junior, and thus for following the Lord Chancellor's implicit pyramidal relationship among the professionals. The third was punished for not having demanded more effort from his junior.

Rewarding the first Queen's Counsel and penalizing the third becomes more understandable when each's junior's compensation

58. If the solicitor's heroic effort explained why this Queen's Counsel took so much less time to prepare, one wonders why he should benefit from the effective work of another.

59. Whatever the explanation, this case illustrates how determining officers did need to evaluate the demands of the case. 
is considered. Since the junior's basic fee is ordinarily a function of the amount received by the leader, ${ }^{60}$ failing to increase the first Queen's Counsel's fee and to decrease the third's would have resulted in unfair payments to each's junior. The first junior would have received much less, and the third much more, than each should when measured both in terms of the time each had taken and each's likely contribution to the defence. But the way of achieving a fair outcome for each junior - fiddling with the Queen's Counsel's award - had its own problems. Instead, it would have been more straightforward and economical to untie the junior's award from the leader's. The junior's remuneration could be increased, as the Queen's Counsel's would not be, because through the junior's efforts the leader was able to prepare more quickly than expected.

In addition to comparing the preparation by barristers representing different defendants, determining officers also compared the time taken by the barrister who returned the brief with that taken by the one who eventually represented the defendant. In one case the brief was returned twice. The first junior's effective hourly rate was $£ 37.50$ while the second's was $£ 62$ even though each had taken the same time to prepare ( 20 hours). For 21 hours of work (16 in preparing, five for the trial's first day), the junior who tried the six-day case earned an hourly rate of $£ 60$. Nothing explains why the first junior received so much less than the other two, or why the second received marginally more than the one

60. The policy of paying the junior half the Queen's Counsel's award is not defended, let alone discussed, in the literature. (Juniors once received a higher amount, two-thirds of the Queen's Counsel's award. Under the new scheme juniors will invariably receive half, no more, no less. See 1996 Legal Aid Regulations, n.5, sch.3, reg.23(1)(c).) It was not only inconsistent with the more general policy of paying a reasonable amount in light of the seriousness of the case and the barrister's contribution to the defence, but, as demonstrated, it could lead to peculiar results. For one, the junior's effective hourly rate could be greater than his leader's, as occurred in number 9 . For another, juniors could receive anomalous amounts when one's effective hourly rate exceeded another's simply because the first junior's leader was forced to take more time to prepare (and thus garnered a high gross basic fee) for the very reason that the first junior had shirked. On the other hand, the policy was certainly easy to administer, eliminating the need to evaluate the junior's work separately from the Queen's Counsel's. 
who tried the case. Should not the third junior have received substantially more than the other two because he shouldered responsibility for the trial? On the other hand, if the two replaced barristers contributed to the defence - each's advice on evidence had sharpened the investigation, for example, or each's conversations with the solicitor were conveyed to the third junior perhaps the third junior should have plowed the same field more quickly than he did. ${ }^{61}$ In the end, the fees awarded to these three juniors remain a mystery.

\section{Defendants represented by a single barrister}

Whatever one thinks of comparing the fees awarded to barristers appearing in the same case and of clustering them around a benchmark reflecting a hypothetical time needed to prepare, it was at least a guide. By contrast, in the majority of cases - those where comparison was impossible because a single defendant was prosecuted and represented by a barrister who did not return the brief - no working rule was discernable.

Consider the basic fees received by Queen's Counsel in the murder trials involving a single defendant. Each Queen's Counsel took between 15 and 26 hours to prepare. In descending order by number of hours worked, the effective hourly rates were: 26 hours yielded $£ 129$ per hour (number 10); 22 hours, $£ 148$ per hour (number 3); 20 hours yielded $£ 200$ per hour (number 48 ) and $£ 140$ per hour (numbers 44 and 45 ); 15 hours, $£ 120$ and $£ 119$ per hour (numbers 35 and 40).

61. On the other hand, the junior who tried the case probably prepared more efficiently than had the junior who received a slightly higher hourly rate. That second junior might not have completed his preparation when he returned the brief. A barrister has an incentive to stop preparing when he begins to worry that the brief may need to be returned. Hence, this second barrister might have needed more than 20 hours to prepare if he had represented the defendant at trial. 
Questions abound..$^{62}$ One of the three Queen's Counsel who hit the determining officer's median - 20 hours - received the highest hourly rate (number 48); the other two (numbers 44 and 45), close to the next highest. Yet in terms of the difficulties posed by the defence, there is no way to explain why the Queen's Counsel in number 48 received $30 \%$ more per hour than did those in numbers 44 and 45 who worked the identical number of hours, or why those three received so much more than did the two (numbers 35 and 40 ) who took the least time to prepare. The policy of increasing the basic fee as if the barrister had taken 20 hours to prepare was not applied in numbers 35 and $40 .{ }^{6}$

The basic fees received by juniors acting alone were often similarly difficult to explain. The effective hourly rate in trials that cracked were: $£ 140, £ 68$ and $£ 59 ; .64$ in jury trials, $£ 81, £ 64, £ 60, £ 43, £ 40$,

62. As the divergence in the basic fees was inexplicable, so were the differences in the refreshers paid to these Queen's Counsel. One received $£ 250$ (of $£ 350$ requested); two, $€ 300$ (of $€ 375$ sought in each instance); five, $£ 350$ (one asked for that amount, three asked for $£ 400$ and the fifth failed to make a request); one, $£ 385$ (of $£ 400$ ); and one, $£ 400$ (amount sought). Because barristers were not expected to say how long they took to prepare for the trial's next day, the refresher was meant to compensate for each five-hour trial day after the first. Hence, the effective hourly rates for these barristers ranged between $£ 50$ and $£ 80$. No determining officer left a mark to explain the amount chosen.

63. The high awards to the two Queen's Counsel who took the longest time to prepare (numbers 10 and three) are perhaps explicable because each shortened the trial. In number 10 , for example, the trial might have been shortened by as many as four days when the defence conceded that the defendant had participated in the murder. Yet, this explanation did not universally apply. In number 35, for instance, the Queen's Counsel said he too had shortened the trial, but nonetheless received the next to lowest hourly rate. Perhaps tellingly, however, he failed to explain what he had done or to estimate the time saved.

64. In a case that ended with an ordered acquittal when the Crown's chief witness was missing and the Judge would not continue the trial to another date, the junior's hourly rate was $£ 37.50$. One might expect that the barrister would receive a much higher basic fee because the judge was freed to take another case. Granted, this junior did nothing to cause the case to go short, but the same could be said about the three cracked trials because in none did the junior indicate how he had contributed to the defendant's decision to plead guilty. 
$£ 36$ and $£ 26$. Of all these awards, in only one - the highest fee for a jury trial - was there a reason that might explain the amount: the junior had to work continuously for eight hours, to prepare a returned brief he received the day before the trial.

Even if the differences in these juniors' hourly rates are unaccountable, the numbers confirm why juniors strove to be briefed in ex post facto cases. Compensation in those cases would dwarf that received in standard-fee cases, as calculated on an hourly basis. The basic fee in standard-fee cases was $£ 214$ in the year of this study (1992 and in 1995). Assuming a junior took three hours to prepare, ${ }^{65}$ his effective hourly rate would be $£ 27$, lower than the amount received by every junior but one ( $£ 26$, number 33 ) in this study. The more obvious advantage of appearing in non-standard cases occurred when the junior was led. The junior's effective hourly rate rocketed up when a leader appeared. His compensation was no longer tied to the time he took, but to an unpredictable, but necessarily higher effective hourly remuneration received automatically by the leader.

\section{ii. Payments for solicitors}

The focus to this point has been on the payments to barristers under the old scheme. Solicitors may want to know how their colleagues fared in the cases examined, as a basis to predict how they will be treated in the future, because the graduated fee scheme does not apply to them.

Solicitors were not treated more deferentially than barristers: their requests were also often cut, and often for no apparent reason. Solicitors suffered in two ways. Determining officers decided that a lower level fee-earner should have performed the work or that the solicitor took too long to complete some task or visited the defendant too frequently.

65. How long juniors took to prepare is not known because they were not required to include the figure. Preparation would ordinarily have been short because the cases were often not complicated and the briefs delivered only immediately before the trial. Nonetheless, juniors would have needed to take some time to read the brief and speak with the instructing solicitor. 
In two settings solicitors were penalized for having done work that demanded less skill than they were presumed to have: a senior solicitor did something that a solicitor could have done; a solicitor appeared at the trial when a clerk should instead have assisted the barrister. ${ }^{66}$

Senior solicitors must reserve their efforts, if they hope to be paid at their hourly rates, for that "small percentage of cases, the most difficult[,] complex or serious ...." ${ }^{\prime 67}$ Senior solicitors would obviously welcome an explanation of that test. While determining officers are expected to explain why a solicitor at a different level should have performed the work, ${ }^{68}$ none did. Tentative conclusions can nonetheless be drawn from the cases studied.

Senior solicitors can expect to be paid at their rate for interviewing the defendant and preparing the brief when the case warrants advocacy by a Queen's Counsel. ${ }^{69}$ That was not universally true, however. In one murder prosecution (number 3) where a Queen's Counsel represented the defendant, the senior solicitor was inexplicably paid at a solicitor's rate. Even when senior solicitors were paid at their level, many seemed to sense that they had to limit their participation. They conducted the first interview with the defendant but not the subsequent ones. They wrote the brief but delegated all other work to a solicitor. The senior solicitor's risk of being compensated at the solicitor's lower hourly rate increases considerably when a junior represented the lay client. One even conceded that he did not deserve his hourly rate, and asked to be

66. Only "fee-earners" within a solicitor's office are compensated for representing an indigent defendant. Fee-earners include a "solicitor, a legal executive or any clerk who regularly does work for which it is appropriate to make a direct charge to a client." Lord Chancellor's Department, Consolidated Regulations, reg. 2 at 2 (1989). Solicitors are further divided by experience, into "senior solicitors" (usually with more than 10 years of experience in criminal cases) and solicitors.

67. See Directions for Determining Officers, n.9, reg. 2B.6 at 20.

68. See Consolidated Regulations, n.66, reg.2B.9, at 22.

69. Fee-earners are paid different hourly rates for different endeavors. For preparing a defendant's case in Crown Court in 1995, for example, the hourly fee was $£ 52.25$ for senior solicitors, $£ 44.25$ for solicitors and $£ 29.55$ for trainee solicitors. The fees were slightly higher for work in London, and each's hourly rate could be increased (an uplift) if the case was especially difficult. 
paid for his 19 hours of preparation at the solicitor's lower rate. ${ }^{70}$ In the 10 other cases the results divided equally, with five senior solicitors paid at their rate and the others paid at the solicitor's lower rate. Unfortunately, these cases yielded no evidence to predict the determining officer's decision. Neither the charges nor the facts distinguished one group from the other, and none of the senior solicitors explained why he, rather than a solicitor, had done the work.

Even when paid at their level, senior solicitors were not always compensated for every hour they worked. In seven instances senior solicitors had their hours sliced for working inefficiently. For example, one senior solicitor was denied payment for eight of 20 hours; another lost 12 of 38 hours; and a third learned he should have prepared the brief in little more than half the time he took.

In theory, cutting the hours for which those senior solicitors were paid makes sense. While an hourly rate induces the solicitor to prepare thoroughly, it also encourages him to dally and to undertake work that promises no more than a marginal benefit to the defence. The problem is to decide when the solicitor could have worked more efficiently. As with the decision over the level of experience needed, here too the untutored eye could divine no explanation for these cuts. There was no evidence in the files to identify the guides that determining officers presumably used to assess the solicitor's effort.

Solicitors who attended the trial were usually paid only at the lowest hourly rate, that for a trainee solicitor. The barrister, whether a leader or a junior, was thus not expected to need more help than that provided by an inexperienced trainee solicitor or perhaps even a person with no legal training. Solicitors understood this rule; few attended the trial. To be paid at his level, then, a solicitor or senior solicitor must defend his decision to assist at the trial. A few did this successfully. One solicitor explained that the junior needed help in selecting the character witnesses from among those available. A senior solicitor justified his appearance on the trial's first day because the defendant had never met the junior who had received the returned brief on the Friday before the trial began on Monday.

70. The offence charged was not included in the papers. 
In the end, the data about solicitors' fees were more tantalizing than instructive. The files did not contain sufficient information to derive whatever rules guided the determining officer. It does seem clear, however, that to be paid at his level a senior solicitor must convince the determining officer that the matter demanded his skill or that because of his skill he completed the work more quickly than a solicitor would have taken.

\section{Conclusion}

The ex post facto scheme had the laudable goal of matching the work done, and its difficulty, with the fee awarded. This study helps in understanding whether there were rules that guided the determining officer's discretion in seeking that goal, and whether those rules were easy to implement. Even with rules, of course, two factors - the determining officer's lack of advocacy experience and often lack of sufficient information from the barrister about his performance - made it difficult to achieve that goal.

As we saw, an important formal rule - rewarding the barrister who shortened the proceeding - was usually followed: To make that general rule more concrete, determining officers developed benchmarks against which to compare the barrister's preparation, either the time assumed to be needed in particular types of cases or the time taken by other barristers in the same case. The outcomes, as the study illustrated, varied widely, and the process was not as predictable as one might like.

The problem with the old scheme, then, was not that the payments were directly correlated to the length of the advocate's preparation, as the Lord Chancellor believed. True, the longer the barrister took to prepare, the higher was the gross amount he received as a basic fee. Yet, that result is less interesting than the fact that the barrister's effective hourly rate typically plummeted as his preparation time exceeded the benchmarks. Instead, the problem was the ostensible unpredictability of the payments (in light of the available information). Perhaps the differences among the 
payments could have been explained, but the answer was not apparent in many files. ${ }^{71}$

On that criticism, scrapping the ex post facto scheme makes sense. Under the new scheme the advocate's compensation is generally not tied to the hours taken to prepare, an advantage in that no one needs to evaluate whether the advocate took less or more time than hypothetically needed. Instead, the expected effort to prepare to defend is implicit in the payments for the number of pages of the Crown's evidence and of its witnesses.

Eliminating the hours taken to prepare as the fulcrum to select compensation has another advantage. Under the old scheme barristers had an incentive to inflate their preparation time. Whether or not suspicious that the hours were padded, determining officers did not verify that the barrister had prepared as long as he claimed, but instead slashed the time on the ground he had prepared inefficiently. Gone is the need for this ruse, apparently developed as a substitute for the imposing task of policing the barrister's records.

It would have been difficult to improve the old system. Although barristers might have been made to provide more information about their efforts, they probably would have balked at such a requirement, and solicitors even now groan under their onerous requirement to report their endeavors.

Moreover, while trained advocates would have more insight into the case's difficulties, the evident replacements for the determining officers might have resisted assuming their function. The obvious candidate was the Judge who presided at the trial, but Judges might

71. It could well be unfair to score the determining officers so roundly. Had they been questioned about the cases in this study, they might have offered convincing explanations for the ostensible anomalies. After all, they were expected to exercise judgment, and judgments can differ over such demanding criteria as they were expected to follow. Even with that concession, however, there were probably no more than six determining officers at the Old Bailey qualified to tax barristers' requests for payment exceeding $£ 4,000$ at the time of this study, an amount commonly sought by the Queen's Counsel in the study's cases. 
have balked at undertaking this mundane (if important) task..$^{72}$ Also, barristers might prefer that Judges not learn how long they took to prepare, and what decisions they made. That sort of information might affect a Judge as he oversaw the barrister in a future case or pondered whether to recommend the barrister for promotion to QC or to the bench. Perhaps by default, trained functionaries, like determining officers, were needed to implement the old scheme.

The graduated fee scheme, then, has the advantage of largely eliminating discretionary judgments. ${ }^{73}$ Abandoned is the fiction that the fee will always match the work required to prepare the brief and to defend once in trial. Some cases that do not fall into one of the narrow discretionary categories will attract fees either too high or too low for the amount of work actually, and properly, undertaken. That said, the new scheme is predictable and open, and enables the Lord Chancellor to control future costs.

Last, although there seems to be no widespread displeasure with the way ex post judgments about the reasonableness of fees are made in other areas, this study suggests a systematic analysis might be of value, if only to confirm that awards are generally justifiable, and thus to allay any suspicions of the occasionally disgruntled barrister or solicitor.

72. However, district Judges, taxing masters and senior executive officers do tax matters in High Court civil matters. Perhaps the participation by Judges orders the way decisions are made so that an inspection of the consistency and predictability of taxation in civil matters is unnecessary.

73. In those areas where determining officers continue to choose the payments under the new approach, the Lord Chancellor should indicate the tests to be employed more carefully than was done under the replaced scheme. While the Lord Chancellor has published a primer for barristers and determining officers to implement the graduated fee scheme, see Guidance to Determining Officers, n.24, it explains only how to apply the pre-set amounts in each category of offence, but ignores how the determining officers are to exercise their discretion. This omission may not be so troubling if the number of $e x$ post facto requests proves to be small. In that event, any variance in payments would probably shrink because only a few determining officers would be needed, and they could police each other as routine ways to evaluate claims were developed. Establishing a single Central Taxing Team to review ex post fncto requests from barristers throughout the country, as the Lord Chancellor is apparently considering, is a step in this direction. 